\title{
Among the Trees
}

\section{By C. STUART FRANCIS, Sprucedale Farm, Torch River}

\section{$\mathbf{I}^{\mathrm{T}}$}

$T$ HAS BEEN a good year for our

trecs. Each season as we try out new species we get more new thrills and surprises.

On our farm we have White Spruce, which have only just emerged from the soil, to some huge giants of over 100 feet tall and containing over 1000 board feet of lumber. Our planted White Spruce have grown from one foot to eighteen inches this season, and many of them have good groups of fresh seed cones on them which will be ripening in September and dropping off, or else opening and letting their seeds fly through the air for many yards.

The Jackpine continues to thrive in all -sorts of weather and seasons, and every year produces very large crops of seed cones of varied shapes and colors. This summer I have young seedlings of two selected specimens of Jackpine; one has very long dark green needles and the other has very short needles, growing very thickly on the twig.

Our Scotch Pines made fast growth - most of them grew a foot or more - and several have produced seed cones for the first time this year. They look very beautiful with their dark blue-green foliage.

Our young, Lodgepole Pines just sprang into the air with new growth of over a foot of lovely dark green very long needles. The Red Pines did not grow so fast, from four to eight inches of new growth of light green shade. Last year's plantings of White Pine and Ponderosa Pine are just getting started.

Did you know that different species of pines have different numbers of needles in their bunches where they grow out from the twig. For example: Jackpine, Scotch Pine, Lodgepole Pine and Red Pine have only two needles to a bunch. Ponderosa Pine has three needles to a bunch, while White Pine has five needles per bunch.

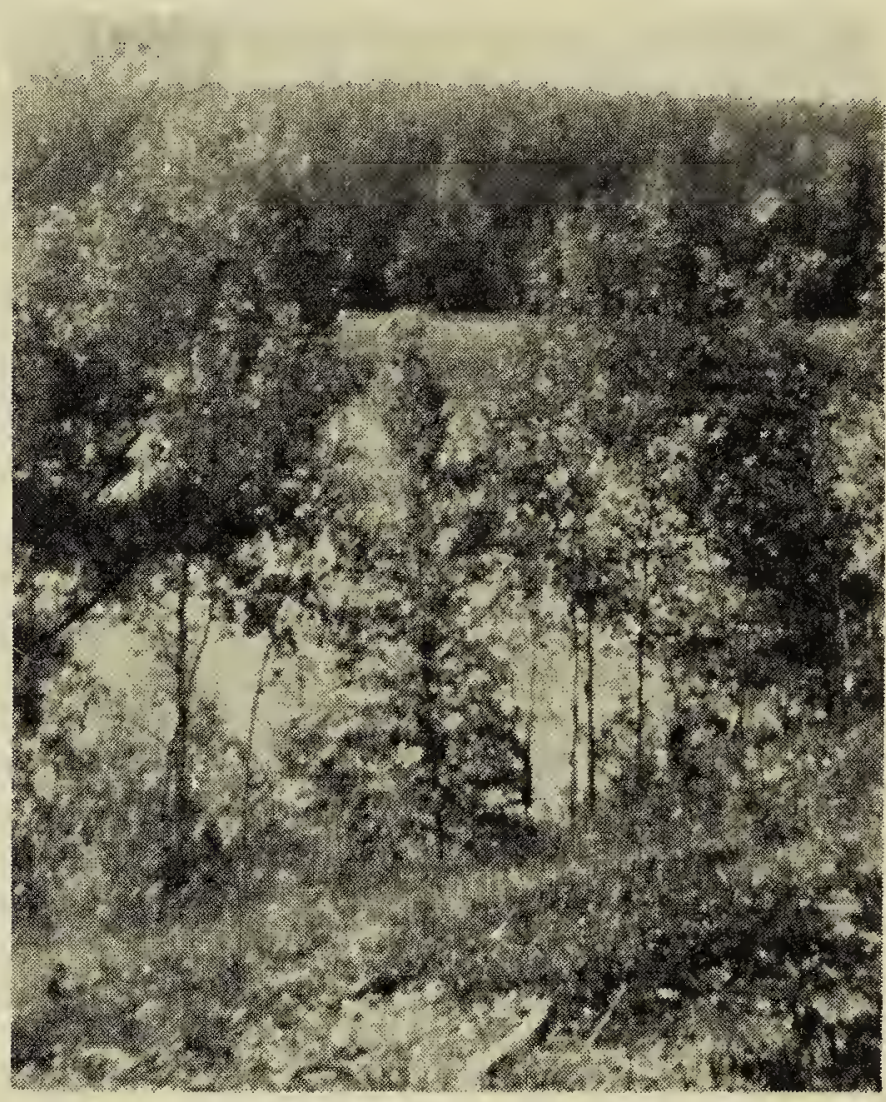

\section{Sprucedale Trees}

Other tiny seedlings of pine, just started from seed this summer, are Austrian Pine and Mugho Pine. Among other evergreen tree species, just started from seed this summer, are the following: White Fir, Colorado Spruce and Himalayan Spruce. Our White Cedar are growing rapidly and are very beautiful in their light green feathery foliage, so different from any of the other evergreens.

If you want to grow trees in a hurry try a few Manchurian Elm not Chinese Elm - as the latter are not hardy. Manchurian Elm will grow up to three feet in one season, and they are a very pretty tree too, with numerous very small light green leaves.

Our Cottonwood seedlings obtained frcm the Forest Nursery at Indian Head last spring, have grown rapidly and are pretty to look at, with the leaves sparkling in the breeze. Among them we have discovered two different separate types; one type resembl-

(Continued on Page 9) 
I'll always remember the scolding of the Rock Wrens. These brown inhabitants of barren, rocky wasteland enlivened many a hot and dusty day.

The first time that I heard the smashing whap in total darkness of a Beaver's tail, I left the ground in positive fright. Now, in knowledge, I enjoy this warning slap. Enjoy the brown head and furrowed water as he sets out in twilight for food.

The Coyote still howls in the Cypress Hills. May he forever do so. How eerie yet how wonderful. The Hills seems wilder for that call. The night and moon move as they were before man.

Each coulee seems to have its deer family. The deer trails. The stray, white, gnawed, discarded ant er. The bedding spots. What a tingling thrill to flush an antlered Buck with flashing tail. What speed, what fluid, effortless jumps.

Snakes have been a rarity in our lives. This rareness was shaken when we met a huge Bull Snake face to face. He was at least four feet in length and I would think one would need both hands to circle his girth. He looked at us with true reptilian disdain and then slowly slithered down into his den.

Here I have seen the Jack, the Cottontail and the Snowshoe Rabbit all living in the same coulee.

On August 27th we encountered twenty mighty Sage Hens. Blackbellied and star-tailed they were a joy to see.

There are still wild herds in the Hills though the Buffalo in their thousands have gone. We thrilled many a time to the sight of from seven to thirty of these brightly colored, faster than all other plain creatures, the true symbol of this corner of the province-the Antelope. Look! See them race over the valley floor then up, up the Frenchman outcrops. See the Buck lagging-guarding the rear. Then they're gone.

Brown and dry is the grass on the Hills as September approaches. Birds have lost their color and their song.
But I have found pleasure that I can never lose. I have found the treasure of blue breasts on orange shale nests.

"Something hidden, go and find it, Go and look behind the ranges, Something lost behind the ranges, Lost and waiting for you Go."

\section{Observations from a City Window}

By H. A. and FRANCES CROOME, Regina, Sask.

Each spring for years we have planted sunflower seed so that in the Fall we may have the pleasure of a visit from the Goldfinches before they travel south.

This year, on August 30, we noticed for the first time a Brewer's Blackbird perched on a sunflower head eating away at the not quite ripe seeds. The next day we counted eight blackbirds swaying on the plants. They seem to have taken possession of the garden and bird bath, chasing from the latter any robin that dares to perch on the edge or tries to go near the water.

\section{Among the Trees \\ (Continued from Page 1)}

ing a Manchurian Pear tree more than anything else, while the other type is quite different from the usual Cottonwood also.

Another beautiful tree is the Butternut or White Walnut, with its spreading habit of growth, with light green soft feeling alternate fifteen to seventeen inch leaves, and yellow twigs.

Now if you want to grow a couple of hardy and pretty native shrubs try the following: the first fairly tall and upright is the Highbush Cran.berry, with its large bunches of white flowers followed by bright red fruits, and the other is the Shrubby Cinquefoil, or Potentilla. It grows to about three feet, is very spreading in shape and is just covered with bright yellow flowers all summer long.

Now it's time to go. I will stroll with you through some of the other trees next time we get a chance. 